\title{
Work in Progress - Enhancing Student-Learning Through State-of-The-Art Systems Level Design and Implementation
}

\author{
Albert A. Liddicoat, Jianbiao Pan, James G. Harris, Dominic J. Dal Bello, and Lynne A. Slivovsky \\ aliddico@calpoly.edu,pan@calpoly.edu,jharris@calpoly.edu, \\ ddalbello@hancockcollege.edu and 1slivovs@calpoly.edu
}

\begin{abstract}
The curriculum for undergraduate engineering programs is often partitioned into several courses that are taught in isolation followed by a single culminating senior design or capstone project experience. In the senior design class students begin to synthesize the knowledge and skills that they acquired through the engineering curriculum. This paper presents lower and upper division course and curricular changes made to accommodate learning objectives that better prepare students for project-based learning. These learning experiences and skills include: systems level design, experience with state-of-the art Computer Aided Design (CAD) tools, printed circuit board (PBC) design, design for manufacturability, electronics assembly, project management, engineering ethics, and communication skills. Three upper division project based learning courses have been developed and are being offered this year. In addition, the development of laboratory tutorials and learning modules for the lower division engineering curriculum will introduce all engineering majors to current electronic manufacturing technology, and allow them to design electronic systems using PCBs. The courses and tutorial learning modules are currently being classroom tested and assessed.
\end{abstract}

Index Terms - Project-based learning, printed circuit board design, systems design, engineering capstone experience

\section{INTRODUCTION}

The challenges associated with preparing engineering graduates for professional practice through a curriculum based on theory and analysis is widely acknowledged [1][3]. Systems level design via novel CAD tools is expected to bring substantial productivity gains to all systems industries including automotive, communication and computing, avionics and building automation, space and agriculture, and health and security [4]. Project-based learning through open-ended system design projects facilitates self-directed learning. Students gain valuable experience applying and synthesizing material from a variety of courses and disciplines. They gain experience as part of a project team that enhances their ability to bridge into professional practice in an era that requires lifelong learning

978-1-4244-1970-8/08/\$25.00 @2008 IEEE and the ability to perform as a member of a multidisciplinary team [5].

Through their experience with project-based learning activities such as the NetPRL lab [6], the authors have uncovered several important curricular issues. First, students often do not have experience with large scale teambased design projects. Secondly, engineering students typically do not acquire printed circuit board design experience. In fact, our experience and research indicate that there are very few universities in the United States that offer courses in printed circuit board design or electronics manufacturing. Thirdly, students often master the course and laboratory work associated with courses in the curriculum, but they do not gain a "systems" level engineering experience that requires them to synthesize what they have learned in their curriculum and extend their knowledge through independent learning that reaches outside their field of study. The need for "systems" level design and multidisciplinary experiences has been echoed by the Cal Poly computer and electrical engineering Industrial Advisory Board (IAB) and the Accreditation Board for Engineering and Technology (ABET) [5]. Figure 1 (a) illustrates the knowledge and skills gap between traditional computer and electrical engineering curricula and those engineering skills required for successful job performance.

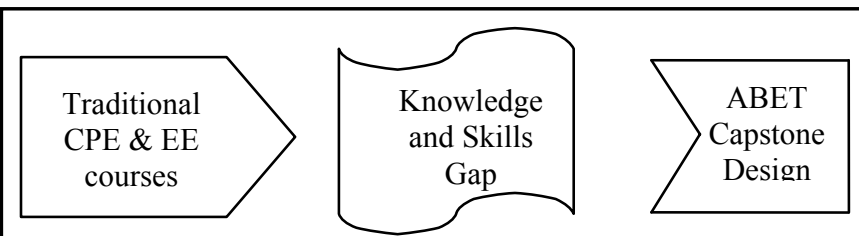

(a) Traditional Computer Engineering Curriculum

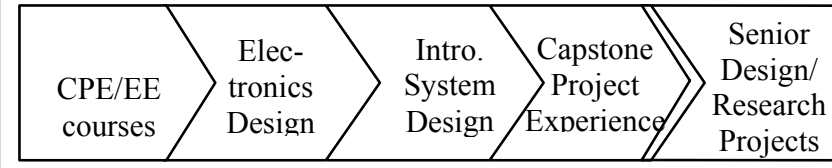

(b) Proposed Computer Engineering Curriculum

Figure 1. Traditional vs. Revised Computer Eng. Curriculum

The authors have created an electronics design and capstone course sequence and they enhanced the October 22 - 25, 2008, Saratoga Springs, NY $38^{\text {th }}$ ASEE/IEEE Frontiers in Education Conference 
Session S3C

microcontroller course to include system design engineering knowledge and skills that better prepare students for their senior design experience as shown in Figure 1(b). In addition, the authors have developed a laboratory learning module for the lower division engineering curriculum to give all engineering students experience with designing, building, and testing printed circuit board systems.

\section{Electronics Design CoURSE}

An upper division technical elective course has been created for students to learn PCB design using CAD tools; this course builds upon the microelectronics, digital and analog design courses in the core courses of the curriculum. The goal of this project-based learning course is to provide students a hands-on experience designing and building multilayer PCBs. The course covers design, layout, fabrication, assembly, and testing of a complex system. Through project-based learning, students develop technical skills in designing and manufacturing an electronic device, as well as project management and communication skills.

\section{SYSTEMS DESIGN COURSE}

In the Introduction to Systems Design course at Cal Poly, students design a custom computing platform using programmable logic with reusable intellectual property core technology [7]. Students also interface this computer system to external hardware devices that include digital and analog $\mathrm{I} / \mathrm{O}$, and develop firmware to best meet the system design requirements. Students analyze system performance based on hardware and software tradeoffs against a backdrop of hardware resource utilization metrics, thus vastly increasing the design space they consider for their projects. This approach expands the learning objectives of the introductory embedded systems courses that use a standard hardware development board. Students now engage in hardwaresoftware co-design, practice hardware reuse, and design and configure a flexible computing platform to best meet the performance, cost, power and design time constraints.

\section{Capstone Design Course Sequence}

A two course capstone design sequence has been created that incorporates team building, design skills, project management, engineering ethics and other related skills [7]. During the two quarter capstone sequence, teams of 4-6 students design and implement a complex system that meets the needs of a real customer. Students meet with a customer to elicit and establish project requirements and complete the conceptual design. The team partitions the system into subcomponents and they document the system architecture, component interfaces, communications protocols and data structures needed for the project. The team presents a design review with the customer before acquiring prototype hardware and development tools.

During the second quarter the team designs the hardware and writes the software. At times, design changes must be made and schedule recovery plans established during the system integration phase. At the end of the second quarter the students work on customer documentation which includes Installation and User manuals, and design documentation. The projects are demonstrated at the College of Engineering Senior Design Fair that is open to students, faculty, project sponsors, and the Cal Poly community.

\section{Lower-division Printed Circuit Design Module}

A learning module is being developed that will allow lower division engineering students to design, fabricate, assemble, and test simple electronic systems implemented on a printed circuit board [9]. The necessary CAD software and fabrication services are provided by low-cost vendors available on the Internet. The laboratory learning module uses operational amplifiers (op-amps), resistors, capacitors and other common electronic components to study circuit theory and to apply these circuits to the interfacing of electronic signals with the physical world. The learning module could be conveniently incorporated into an existing engineering course/lab to meet and extend the laboratory learning objectives, including those at community colleges.

\section{CONClusions}

Three courses establish a critical pathway in the computer engineering curriculum to properly prepare students for the workforce and for graduate studies by engaging them earlier in project-based learning activities and developing the skills needed to contribute to significant team-based development projects. A self-contained lower-division learning module will allow all engineering students to experience PCB design and fabrication.

\section{ACKNOWLEDGMENT}

This work is sponsored by the National Science Foundation Course, Curriculum, and Laboratory Innovation (NSFCCLI) program, under award DUE-0633363. The authors wish to acknowledge the contribution to this project by their students: Ron Sloat, Edward Adams and Greg LaCaille.

\section{REFERENCES}

[1] Friesen, M. and Taylor, K. L., "Perceptions and Experiences of Industry Co-Operators in Project-Based Design Courses," Int. Journal of Engineering Education, Vol. 23, No. 1, pp, 114-119, 2007.

[2] Gorman, M. E., Johnson, V. S., Ben-Arieh, D. Bhattacharyya, S., Eberhart, S., Glower, J., et al., "Transforming the Engineering Curriculum: Lessons Learned from a summer at Boeing," Journal of Engineering Education, Vol. 90, No. 1, pp, 143-149, 2001.

[3] Nicolai, L. M., "Viewpoint: an Industry View of Engineering Design Education," International Journal of Engineering Education, Vol. 14, No. 1, pp. 7-13, 1998

[4] Sangiovanni-Vincentelli, A. "Quo Vadis, SLD? Reasoning about the Trends and Challenges of System Level Design," in Proc. of the IEEE, Vol. 95, No.3, March 2007, pp.467-506.

[5] Accreditation Board for Engineering and Technology 2000, Criteria for Accrediting Engineering Programs, http://www.abet.org/.

[6] Cal Poly iDesign website, http://iDesign.calpoly.edu/.

[7] Liddicoat, A., Pan, J., Harris, J., and Slivovsky, L., "Curricular Enhancement to Support Project-Based Learning in Computer and

October 22 - 25, 2008, Saratoga Springs, NY $38^{\text {th }}$ ASEE/IEEE Frontiers in Education Conference

S3C-14 
Electrical Engineering," Proceedings of the $115^{\text {th }}$ ASEE Annual Conference, June 2008.

[8] Harris, J., Dal Bello, D., Pan, J., and Liddicoat, A., "Enhancing Student Learning Through State-of-the-Art Systems Level Design and Implementation: The Development of a Lower Division Learning Module," Proc. of the $115^{\text {th }}$ ASEE Annual Conference, June 2008.

[9] Pan, J., Harris, J., Liddicoat, A., and Dal Bello, D., "A Project-Based Electronics Manufacturing Laboratory Course for Lower-Division Engineering Students," Proceedings of the $115^{\text {th }}$ ASEE Annual Conference, June 2008. 